\title{
El periodismo que vuela
}

El periodismo que vuela. Drones, 3D,

Smarthpones y Robots, Tecnologías

emergentes para la profesión periodística

Ángeles Fernández Barrero

Sevilla: Fénix Editora, 2018.

172 páginas

ISBN: 978-8-948052-5-7

Reseña realizada por Gladys Arlette Corona-León

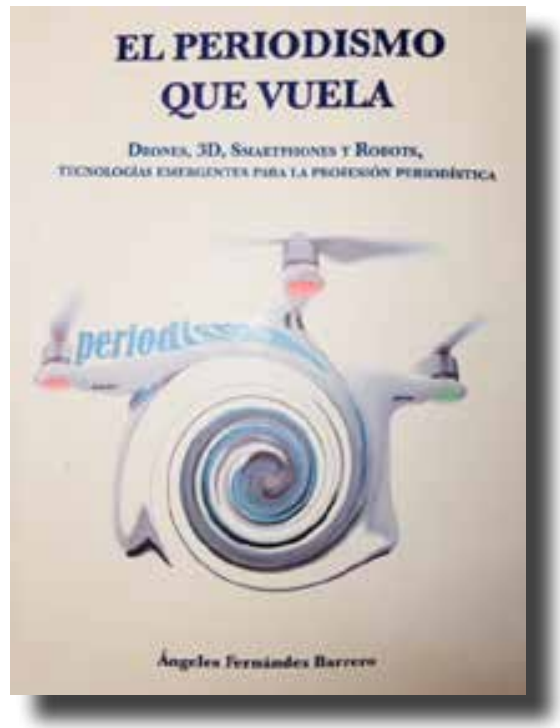

El libro abre sus alas hacia el rumbo que están tomando los drones en el periodismo. El uso de estos vehículos aéreos no tripulados, ha pasado de las prácticas militares a las prácticas periodísticas, de arma de guerra teledirigida a herramienta de trabajo para hacer noticias.

Son muchos los beneficios que aportan los drones a la narrativa periodística. Entre otras cosas podemos considerar que cuidan la integridad del periodista, graban imágenes y hacen fotos, la subcontratación de este servicio tiene un precio accesible, no se necesita postproducción, este vuelo teledirigido accede a la zona donde se encuentra la noticia y le brinda valor añadido a lo que se transmite. Por otro lado, las posibles desventajas, son aparatos sensibles a las condiciones climáticas, pueden presentar accidentes, se necesita conocer la normativa de su uso y gente especializada para operarlo.

La profesora Fernández Barrero explica en esta obra cómo el periodismo interactivo da lugar al periodismo in- 
mersivo, el cual se integra por la realidad virtual, la realidad aumentada y los vídeos grabados en 360 grados, los cuáles ponen a volar la imaginación del participante, que aterriza y se mueve en la atmósfera en la que se desarrolla la narración.

A continuación se trata el periodismo que se está desarrollando desde los smarthphones, el "mobile journalism". Estos dispositivos móviles han cambiado el qué y el cómo se produce el contenido informativo, así como los hábitos de consumo del público. Ante este escenario donde la información es ubicua, es decir, que se presenta de manera global e instantánea, los periodistas tienen la responsabilidad de ser, ahora más que nunca, profesionales multitask. Es en este apartado, donde la autora nos menciona, que la rama periodística al igual que la tecnología, se encuentra en constante evolución y para no perder el piso, nos sugiere un decálogo del periodismo móvil.

Por último, hace referencia a la cercanía que ha tenido el periodismo con la tecnología, desde la imprenta de Gutenberg, hasta el periodismo robotizado de alta tecnología o hi- tech. Pasando por varias revoluciones históricas, pero el elemento más significativo y que lo ha cambiado todo, ha sido el uso de internet, el cual ha desencadenado un gran consumo de información por parte de la audiencia que, al no poder ser cubierto por los mismos humanos, da pie a la entrada a escena de la narrativa automatizada.

La fórmula que sigue cada uno de los cuatro capítulos del libro es, dar a conocer el marco histórico, los conceptos clave, compartir cómo se lleva a cabo cada tipo de periodismo que se expone, tanto en España como en el mundo y cómo los grupos mediáticos los utilizan para producir información.

Se pone sobre la mesa la responsabilidad que tienen los medios de comunicación y la importancia que surge cuando ellos tienen la oportunidad de adquirir nuevos programas o equipos, pues el contenido que produzcan le permitirá al espectador estar al alcance de conocer diversas maneras en las que la información es presentada.

Leer este libro, permitirá entender el planear del vuelo que están tomando las nuevas tecnologías en el periodismo, herramientas que están al servicio de la información y que permiten nuevas formas de narrativa, donde se tiene un papel más empático o más próximo al espectador o usuario, el cual decide a qué tipo de información decide acceder y de que forma. 